\title{
Influence of 6-week, 6 days per week, training on pituitary function in recreational athletes
}

\author{
M. Lehmann MD, K. Knizia MD, U. Gastmann MD, K. G. Petersen MD*, \\ A. N. Khalaf MD*, S. Bauer Dipl Oec Troph, L. Kerp MD* and J. Keul MD \\ Department of Sports and Performance Medicine and *Department of Endocrinology, University Clinic Freiberg, \\ Freiberg, Germany
}

The influence on pituitary function of 6 weeks of training on 6 days a week was examined in six recreational athletes. Endurance training on a bicycle ergometer for 31-33 min was performed on 4 days each week at $90-96 \%$ (weeks 1-3) and $89-92 \%$ (weeks 4-6) of the $4 \mathrm{mmol}$ lactate thresholds determined on day 0 and day 21, respectively, with interval training of 3-5 $\times 3-5 \mathrm{~min}$ in addition on 2 days a week at $117-127 \%$ and $115-110 \%$, respectively. Determination of the serum hormone levels and a combined pituitary function test $(200 \mu \mathrm{g}$ thyrotropin releasing hormone (TRH), $100 \mu \mathrm{g}$ gonadotrophin-releasing hormone $(\mathrm{GnRH}), 100 \mu \mathrm{g}$ corticotrophin releasing hormone (CRH), $50 \mu \mathrm{g}$ growth hormone releasing hormone (GHRH)) were made before training, after 6 weeks of training and after another 3 weeks of recovery. Training increased performance at $2 \mathrm{mmol}$ lactate by $25 \%$, at $4 \mathrm{mmol}$ by $12 \%$, and maximum performance by approximately $12 \%$. The releasing hormone-stimulable prolactin, thyroid stimulating hormone (TSH) and somatotrophic hormone (STH) synthesis-secretion capacity remained unchanged, the adrenocorticotrophic hormone (ACTH) was increased after training. Cortisol release was reduced, folliclestimulating hormone (FSH)-synthesis-secretion capacity was increased after training, and the luteinizing hormone (LH)-synthesis-secretion capacity reduced. This had no influence on base or exercise-induced serum hormone levels (cortisol, aldosterone, insulin, prolactin, FSH, LH, TSH, ACTH, ADH and STH), which showed no dependence on training, except for free testosterone which showed a decreasing trend $(P<0.10)$ of $19-25 \%$ and post-exercise ACTH which showed an increasing trend of $33 \%(P<0.10)$. Conditioning (cortisol sensitivity and ACTH response) or adaptation (FSH and $\mathrm{LH}$ responses) to changed testosterone serum levels and altered spermatogenesis is discussed.

Keywords: Training, hormones, pituitary function

Neuroendocrine $^{1}$ and neurovegetative impairments ${ }^{2}$ are assumed to occur in the overtraining syndrome of endurance athletes ${ }^{2,3}$. In exhausted endurance athletes, Barron et al. ${ }^{1}$ found a lower release of $\mathrm{ACTH}$, cortisol, STH and prolactin following insulininduced hypoglycaemia. This is based, however, on a

Address for correspondence: Professor Dr M. Lehmann,

University Clinic Freiburg, Department of Sports and Performance

Medicine, Hugstetter Strasse 55, D-7800 Freiburg, Germany

(C) 1993 Butterworth-Heinemann Ltd

0306-3674/93/030186-07 hypothalamic and not a pituitary dysfunction, since luteinizing hormone releasing factor (LHRF) and TRH-induced $\mathrm{LH}, \mathrm{TSH}$ and prolactin responses corresponded to that in well trained athletes. But Keizer et al. ${ }^{4}$ also describe signs of pituitary impairment with reduced $\mathrm{CRH}$-dependent $\beta$-endorphin release after exhaustive training. Hackney et al. ${ }^{5}$ found a higher metoclopramide-induced prolactin release and reduced LHRF-dependent LH release in non-overtrained marathon runners than in untrained controls; the base LH levels of the marathon runners tended to be higher, and the base levels of free testosterone lower than in untrained controls. Wheeler et al. observed unchanged single-sample LH and FSH levels and LH pulsatile release with significantly lower levels of prolactin, cortisol and total testosterone after 6 months of race training ${ }^{6}$. The reduced testosterone levels are therefore not attributable to reduced gonadotrophin secretion or excessive cortisol levels.

The object of this investigation was the prospective, experimental study of pituitary adaptation to physical training in previously untrained or lesstrained individuals. For this, a global pituitary function test was performed before starting training, after 6 weeks of training on 6 days each week, and after another training-free period of 3 weeks. The influence of experimental overtraining on pituitary function is to be examined in subsequent studies.

\section{Subjects and methods}

\section{Subjects}

Seven medical or dental students who participate in sports $1-2 \mathrm{~h}$ per week were enrolled in this study. Anthropometric data and maximum oxygen uptake capacity are presented in Table 1 . The subjects were

Table 1. Anthropometric data and oxygen uptake capacity $\left(\dot{V}_{\mathrm{O}_{2} \text { max }}\right)$

\begin{tabular}{lccccc}
\hline$n$ & $\begin{array}{c}\text { Age } \\
\text { (years) }\end{array}$ & $\begin{array}{c}\text { Height } \\
(\mathrm{cm})\end{array}$ & $\begin{array}{c}\text { Weight } \\
(\mathrm{kg})\end{array}$ & $\begin{array}{c}\dot{V}_{\mathrm{O}_{2 \max }} \\
\text { Day 0 }\end{array}$ & $\begin{array}{c}\left(\mathrm{m} / \mathrm{kg}^{-1} \mathrm{~min}^{-1}\right) \\
\text { Day } 43\end{array}$ \\
\hline 6 & $26(1)$ & $185(9)$ & $79(7)$ & $52.0(5.2)$ & $54.9^{*}(5.8)^{*}$ \\
\hline
\end{tabular}

Values are mean(s.d.). ${ }^{*} P<0.05$ 
informed of the study procedure, objectives and possible complications; they granted written informed consent. Approval by Ethics Commission vote was obtained.

\section{Procedure}

Training was performed for 6 weeks, on 6 days of the week (days $0-42$ ), followed by a training-free period of 3 weeks (days 43-63). Clinical and blood chemical examinations and performance diagnostic tests (incremental bicycle test) were performed on days 0,21 , 42 and 63 . The subjects reported to the outpatient clinic on these days after a light breakfast, always at the same time in the early morning.

Training (Table 2) was performed in the laboratory seated on a bicycle ergometer. A training session of at least $30 \mathrm{~min}$ was performed 4 days a week on average with $90 \%, 95 \%$ and $96 \%$ (weeks $1-3$ ) or $89 \%, 89 \%$ and $92 \%$ (weeks $4-6$ ) of the $4 \mathrm{mmol}$ lactate performance at baseline examination (day 0 ) or interim examination (day 21). Interval training of 3-5 $\times$ 3-5 min was performed 2 days each week on average with $117 \%, 124 \%$ and $127 \%$, or $115 \%, 116 \%$ and $110 \%$ (Table 2). Detailed information on the duration of training is given in Table 2. Initial exercise phases of $10 \mathrm{~min}$ at approximately $50 \%$, interim exercise of $5 \mathrm{~min}$ at approximately $30 \%$ (only in the interval training) and final exercise phases of $10 \mathrm{~min}$ at approximately $30 \%$ of maximum performance are not reflected in the times cited. Well-being, body weight, heart rate on waking and training were entered in a diary daily by the subjects and the general well-being rated according to an index. Index 1 indicates no complaints, 2 indicates mild, 3 considerable complaints, such as fatigue and muscular stiffness causing reduction in training, and index 4 severe complaints causing termination of training.

\section{Diet}

The usual diet was maintained and entered in a protocol every 2-3 days. Medications, food concentrates, mineral drinks, vitamin tablets, etc. were not permitted. None of the subjects smoked, and usual alcohol consumption was permitted. The dietary protocols were evaluated using a computer ${ }^{7,8}$.

\section{Performance diagnostics}

The seated bicycle ergometer test was performed on days $0,21,42$ and 63 on a revolution-independent, electromagnetically braked ergometer with an initial performance of 100 watts. The performance level was increased after every $3 \mathrm{~min}$ of exercise by 50 watts until subjective exhaustion was reached. Capillary blood samples were taken for lactate determination according to Hohorst ${ }^{9}$ and an electrocardiogram was recorded before exercise, in the last $30 \mathrm{~s}$ of each exercise level and immediately after the termination of exercise. The performance at 2 and $4 \mathrm{mmoll}^{-1}$ lactate was used as the parameter for extensive and intensive submaximum performance, respectively, based on the lactate-performance ratio by interpolation; the maximum power and total work in the incremental test were used as parameters of maximum performance.

\section{Serum hormone levels}

Venous blood was drawn after a 30-min resting period in the supine position and after exhaustive exercise on days 0,42 and 63 to determine the following hormones: cortisol (RIA Cortisol Bridge, Serono, Freiburg, Germany), aldosterone (RIA Aldosterone AIA, Serono), free testosterone (RIA, Biermann, Bad Nauheim, Germany), insulin and C-peptide (RIA Gnost Insulin and hC-Peptide, Behringwerke, Marburg, Germany), growth hormone (hGH 100, Pharmacia Diagnostics, Uppsala, Sweden), prolactin (Prolactin AIA Clone, Serono), follicle stimulating and luteotrophic hormone (FSH/ LH AIA Clone RIA, Serono), thyroid stimulating hormone (hTSH RIA Gnost, Behringwerke). All the samples from one subject were processed in one assay to avoid interassay variability.

\section{Pituitary function test}

A combined pituitary function test was performed on days 1,43 and 63 . The test consists of concurrent administration of $200 \mu \mathrm{g}$ thyrotrophin-releasing hormone (TRH), $100 \mu \mathrm{g}$ gonadotrophin-releasing hormone $(\mathrm{GnRH})$, $50 \mu \mathrm{g}$ growth hormone-releasing hormone (GHRH) and $100 \mu \mathrm{g}$ corticotrophin-releasing hormone (CRH) (Bissendorf Peptide, Hannover,

Table 2. Training data

\begin{tabular}{|c|c|c|c|c|c|c|}
\hline & & & & & & \\
\hline & 1 & 2 & 3 & 4 & 5 & 6 \\
\hline Endurance training* & & & & & & \\
\hline Workload (watt) & 219(31) & $231(32)$ & $232(36)$ & 233(33) & $233(62)$ & $241(40)$ \\
\hline$(\%$ of $4 \mathrm{LT})$ & $90+$ & $95 t$ & $96 t$ & $89 \neq$ & $89 \neq$ & $92 \ddagger$ \\
\hline Work time (min) & $33(4)$ & $31(3)$ & $31(3)$ & $31(3)$ & 31(3) & $32(4)$ \\
\hline Interval training§ & & & & & & \\
\hline Workload (watt) & 284(55) & $300(61)$ & $307(59)$ & $302(53)$ & $304(52)$ & $289(58)$ \\
\hline$(\%$ of $4 \mathrm{LT})$ & $117 t$ & $124 t$ & $127 t$ & $115 \ddagger$ & $116 \neq$ & $110 \neq$ \\
\hline Work time $(\mathrm{min})$ & $3.42(0.85)$ & $3.71(0.91)$ & $3.71(0.91)$ & $4.43(0.94)$ & $4.42(0.90)$ & $4.42(0.90)$ \\
\hline Intervals & 3 & 3.14 & 3.14 & 3 & 3.17 & 3 \\
\hline
\end{tabular}

Values are mean(s.d.). 4 LT, 4 mmol lactate threshold *On 4 days per week; tBased on day 0 examination; $\neq$ Based on day 21 examination; $\S$ On 2 days per week 
Germany); it was administered intravenously via an indwelling cannula after a resting period of $1 \mathrm{~h}$ supine and an additional $15 \mathrm{~min}$ pre-phase. Venous blood was drawn to determine ACTH, cortisol, prolactin, $\mathrm{TSH}, \mathrm{HGH}, \mathrm{FSH}, \mathrm{LH}$ and free testosterone at the following times: $-15 \mathrm{~min}, 0,30,45,60$ and $90 \mathrm{~min}$.

\section{Assessment and statistics}

Means and standard deviations were calculated for the individual measured parameters, medians and central $50 \%$ confidence ranges were calculated for STH as the measurements did not approximate to the normal distribution. Significance testing was carried out using the Wilcoxon signed ranks test for related pairs. An error probability of $P<0.05$ was considered significant.

\section{Results}

The results are summarized in Tables 1-6 and presented graphically in Figures 1-3. After about 3

Table 3. Heart rate and body weight

\begin{tabular}{lccc}
\hline & \multicolumn{3}{c}{ Day } \\
& 0 & 42 & 63 \\
\hline Body weight $(\mathrm{kg})$ & $79(7)$ & $80(8)$ & $80(10)$ \\
$\begin{array}{l}\left.\text { Heart rate (beats } \text { min }^{-1}\right) \\
\quad \text { Resting }\end{array}$ & $58(7)$ & $52(8)$ & $55(10)$ \\
Before exercise* & $72(9)$ & $75(11)$ & $83(7)$ \\
Submaximum exerciset & $145(19)$ & $141(10)$ & $152(27)$ \\
Maximum exercise & $190(12)$ & $187(7)$ & $186(12)$ \\
\hline
\end{tabular}

Values are mean(s.d.). *Sitting; †Workload 200 watts; $¥$ See Table 5

Table 4. Nutrition data

\begin{tabular}{lc}
\hline Total calorific intake per day (kcal) & $2815(647)$ \\
Carbohydrates (\%) & $45(6)$ \\
Lipids (\%) & $35(6)$ \\
Proteins (\%) & $14(2)$ \\
Alcohol (\%) & $6(4)$ \\
\hline
\end{tabular}

Values are mean(s.d.) weeks of training, one subject became ill with a febrile catarrhal infection; frequent ventricular extrasystoles occurred and the subject dropped out of the study for this reason.

Body weight (Table 3) and heart rate on waking, before exercise, at the same submaximum exercise level and during maximum exercise remained constant (Table 3). The dietary data are shown in Table 4 and training data in Table 2.

Training improved performance significantly after 3 weeks at 2 and $4 \mathrm{mmoll}^{-1}$ lactate. Performance at $2 \mathrm{mmol}$ lactate had decreased again after 6 weeks of
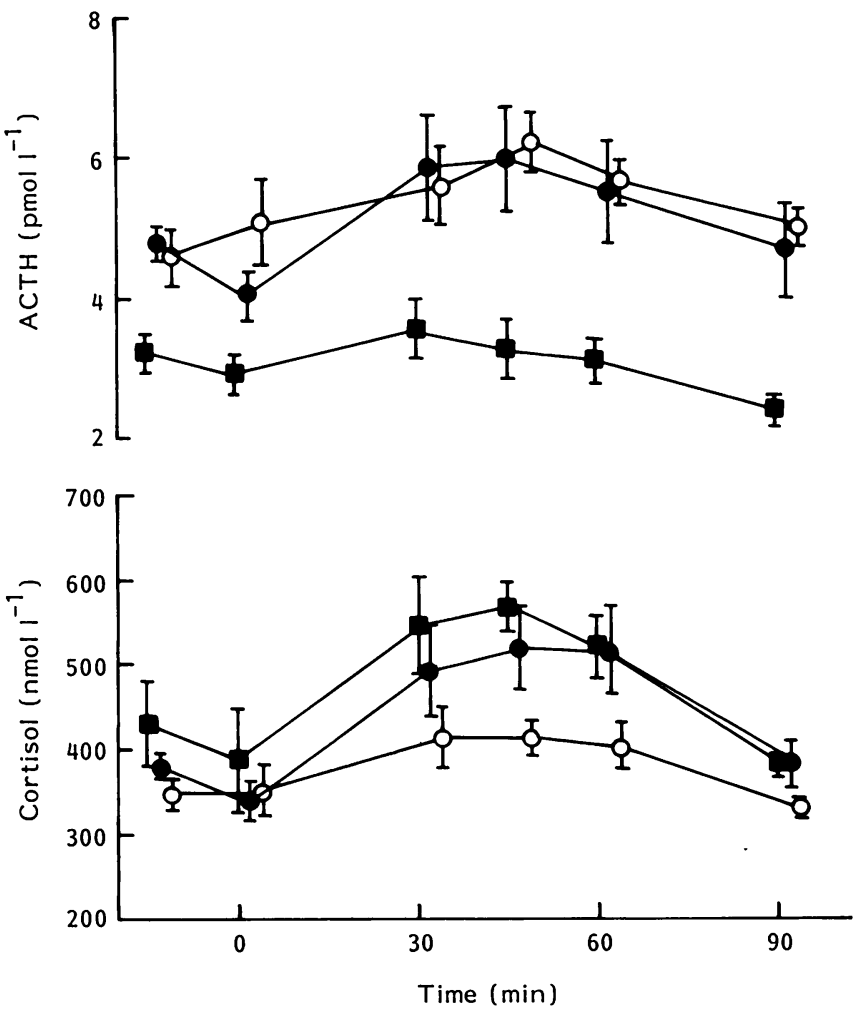

Figure 1. Combined pituitary function test: $\mathrm{ACTH}$ and cortisol responses to CRH in six subjects before ( $\square$ ), after 6 weeks of training (O), and additional 3 weeks of recovery (O). The ACTH response to CRH is significantly increased after 6 weeks of training, and after the additional 3 weeks of recovery, the cortisol response to ACTH is decreased after the recovery period. Values are mean(s.d.)

Table 5. Performance data

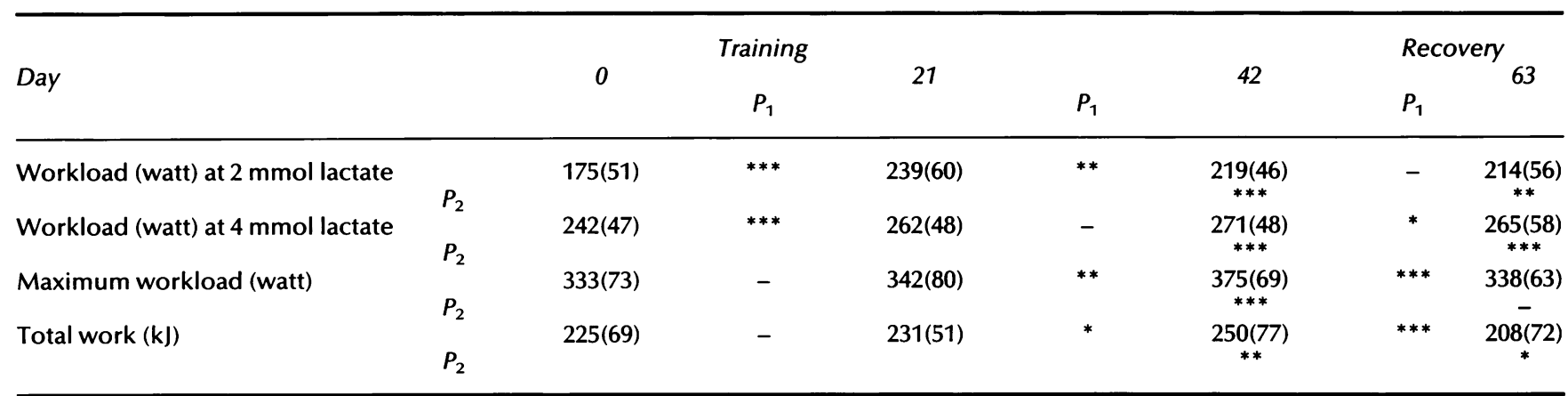

$P_{1}$ Statistical examination between days 0 and 21, 21 and 42,42 and $63, P_{2}$ Statistical examination between day 42 and baseline, and 63 and baseline.

${ }^{*} P<0.05 ;{ }^{* *} P<0.01 ;{ }^{* * *} P<0.001$. 
training, but was further improved at $4 \mathrm{mmol}$. The maximum performance increased by about 40 watts (Table 5).

Performance at $2 \mathrm{mmol}$ and $4 \mathrm{mmol}$ lactate was slightly decreased after the subsequent 3 training-free weeks; the decrease in maximum performance was more pronounced (Table 5), probably due to lower motivation to reach peak exercise.

The mean(s.d.) complaint index in the first week was $1.3(0.3)$, in the third week $1.51(0.8)$ and in the sixth week 1.70(0.9); this change was not significant.

\section{Hormone levels}

The basal hormone levels and concentrations following maximum exercise were unchanged at the various examination times (Table 6); the decrease in free testosterone did not reach a statistically significant level.

\section{Pituitary function test}

The releasing hormones produced a significant increase in ACTH (Figure 1), STH, TSH, prolactin (Figure 2), LH and FSH (Figure 3), ACTH is shown relative to increase in cortisol (Figure 1), and LH to increase in free testosterone after 60 and $90 \mathrm{~min}$ (Figure 3). ACTH release was elevated after 6 weeks of training and LH release was reduced (Figures 1 and 3 ). These changes were still observed after 3 weeks of recovery. At that time, FSH release was also elevated (Figure 3). Cortisol release (Figure 1) was significantly reduced after 6 weeks of training and 3 weeks of recovery, free testosterone showed a comparable tendency (Figure 3), but the data were widely scattered and differences were not statistically significant. STH, TSH and prolactin release did not show any training-related changes (Figure 2).

\section{Discussion}

The training routine improved submaximum and maximum performance (Table 5). The data can, however, only be compared with other experimental studies to a limited degree due to different training programmes and initial performance capacity (among others ${ }^{10-15}$ ). Improvement in maximum oxygen uptake by $13 \%{ }^{11,12}, 15 \%^{10}, 22 \%^{15}, 27 \%^{14}$ and $40 \%^{13}$ has been reported in endurance training of 20 weeks, 4 days a week ${ }^{11}, 12$ weeks, 5 days a week ${ }^{12}, 7$ weeks, 4 days a week ${ }^{10}{ }^{\prime}, 7$ weeks, 7 days a week ${ }^{15}, 20$ weeks, 3 days a week ${ }^{14}$ and 10 weeks, 6 days a week ${ }^{13}$. The mean initial oxygen uptake was $45^{11}, 41^{12}, 42^{10}, 45^{15}$, $33^{14}$, and $39 \mathrm{ml} \mathrm{kg}^{-1} \mathrm{~min}^{-1}$ (Reference 13), and was thus considerably lower than in this present study (Table 1). The improvement of submaximum and maximum performance depends on the intensity, frequency, duration, period of training, initial performance capacity and genetic predisposition (among others $^{11,13,16}$ ). The higher the initial performance and the lower the genetically determined reserves, the more difficult it is to attain additional, trainingrelated improvement in performance $e^{17,18}$ and the narrower the margin to overtraining $2,3,17,18$.

Table 6. Serum hormone levels*

\begin{tabular}{|c|c|c|c|c|c|c|}
\hline \multirow{2}{*}{$\frac{\text { Day }}{\text { ACTH }\left(\mathrm{pmol} \mathrm{I}^{-1}\right)}$} & \multicolumn{2}{|c|}{0} & \multicolumn{2}{|c|}{42} & \multicolumn{2}{|c|}{63} \\
\hline & 4.4 & 0.9 & 4.4 & 0.9 & 4.8 & 0.7 \\
\hline \multirow{3}{*}{$\mathrm{ADH}\left(\mu \mathrm{U} \mathrm{ml^{-1 } )}\right.$} & $9.9^{*}$ & 5.5 & $13.2^{*}$ & 6.6 & $11.9^{*}$ & 4.3 \\
\hline & 1.56 & 0.48 & 1.20 & 0.52 & 1.28 & 5.96 \\
\hline & ME $\quad 6.36+$ & 3.61 & $6.84 t$ & 2.84 & $5.96 t$ & 2.72 \\
\hline \multirow[t]{2}{*}{ Prolactin $\left(\mathrm{mU} \mathrm{ml}^{-1}\right)$} & BE 262 & 128 & 153 & 56 & 324 & 110 \\
\hline & ME 277 & 62 & 366 & 208 & 316 & 58 \\
\hline \multirow[t]{2}{*}{$\mathrm{FSH}\left(\mathrm{mU} \mathrm{ml^{-1 } )}\right.$} & $\mathrm{BE} \quad 2.7$ & 0.7 & 2.7 & 0.7 & 2.7 & 0.8 \\
\hline & $3.0^{*}$ & 0.8 & 3.2 & 1.2 & 3.2 & 0.9 \\
\hline \multirow[t]{2}{*}{$\mathrm{LH}\left(\mathrm{mU} \mathrm{ml} \mathrm{l}^{-1}\right)$} & 2.3 & 0.4 & 2.0 & 0.5 & 1.9 & 0.3 \\
\hline & 2.2 & 0.4 & 2.0 & 0.4 & 1.9 & 0.3 \\
\hline \multirow[t]{2}{*}{$\mathrm{TSH}\left(\mu \mathrm{U} \mathrm{ml} \mathrm{l}^{-1}\right)$} & 1.50 & 0.80 & 1.00 & 0.62 & 1.01 & 0.81 \\
\hline & ME $\quad 1.70$ & 0.84 & 1.15 & 0.56 & 1.14 & 0.81 \\
\hline \multirow[t]{2}{*}{ Cortisol (nmol I-1) } & BE 458 & 163 & 414 & 88 & 477 & 119 \\
\hline & ME 309 & 83 & 389 & 166 & 353 & 39 \\
\hline \multirow[t]{2}{*}{ Aldosterone $\left(\mathrm{nmol} \mathrm{I}^{-1}\right)$} & BE 499 & 461 & 602 & 524 & 475 & 208 \\
\hline & ME1212† & 969 & $1173^{*}$ & 391 & $1129^{*}$ & 395 \\
\hline \multirow[t]{2}{*}{ Free testosterone $\left(\mathrm{pmoll}^{-1}\right)$} & BE 105 & 34 & 102 & 41 & 85 & 20 \\
\hline & ME $136^{*}$ & 34 & 102 & 20 & 102 & 17 \\
\hline \multirow[t]{2}{*}{ PRA (ng ml-1 $h^{-1}$ ) } & $\mathrm{BE} \quad 1.4$ & 0.8 & 1.6 & 1.4 & 1.0 & 0.2 \\
\hline & $6.3+$ & 3.7 & $8.6+$ & 2.9 & 8.4* & 7.7 \\
\hline \multirow[t]{2}{*}{ Insulin $\left(\mu \cup \mathrm{ml}^{-1}\right)$} & 18 & 7 & 13 & 9 & 25 & 10 \\
\hline & $\mathrm{ME}$ & 10 & 12 & 5 & $12^{*}$ & 4 \\
\hline \multirow[t]{2}{*}{ C-petide (ng ml-1) } & 3.1 & 0.9 & 2.7 & 0.7 & 4.1 & 1.0 \\
\hline & ME & 0.9 & 2.7 & 0.7 & 2.8 & 0.7 \\
\hline \multirow{3}{*}{ STH (ng ml-1) } & Median & $50 \%$ c.i. & Median & $50 \%$ c.i. & Median & $50 \%$ c.i. \\
\hline & $\mathrm{BE} \quad 0.15$ & $0.1-0.2$ & 0.20 & $0.1-0.3$ & 0.20 & $0.1-0.3$ \\
\hline & ME $7.50^{*}$ & $3.0-11.5$ & $5.71^{*}$ & $2.0-31.0$ & $9.04^{*}$ & $5.2-12.6$ \\
\hline
\end{tabular}

*ACTH, ADH (antidiurectic hormone) and PRA (plasma renin activity) were measured in plasma. BE, before exercises; ME, maximum graded exercise (see Table 5); c.i. confidence interval. ${ }^{*} P<0.05,+P<0.01$ (BE versus ME) 

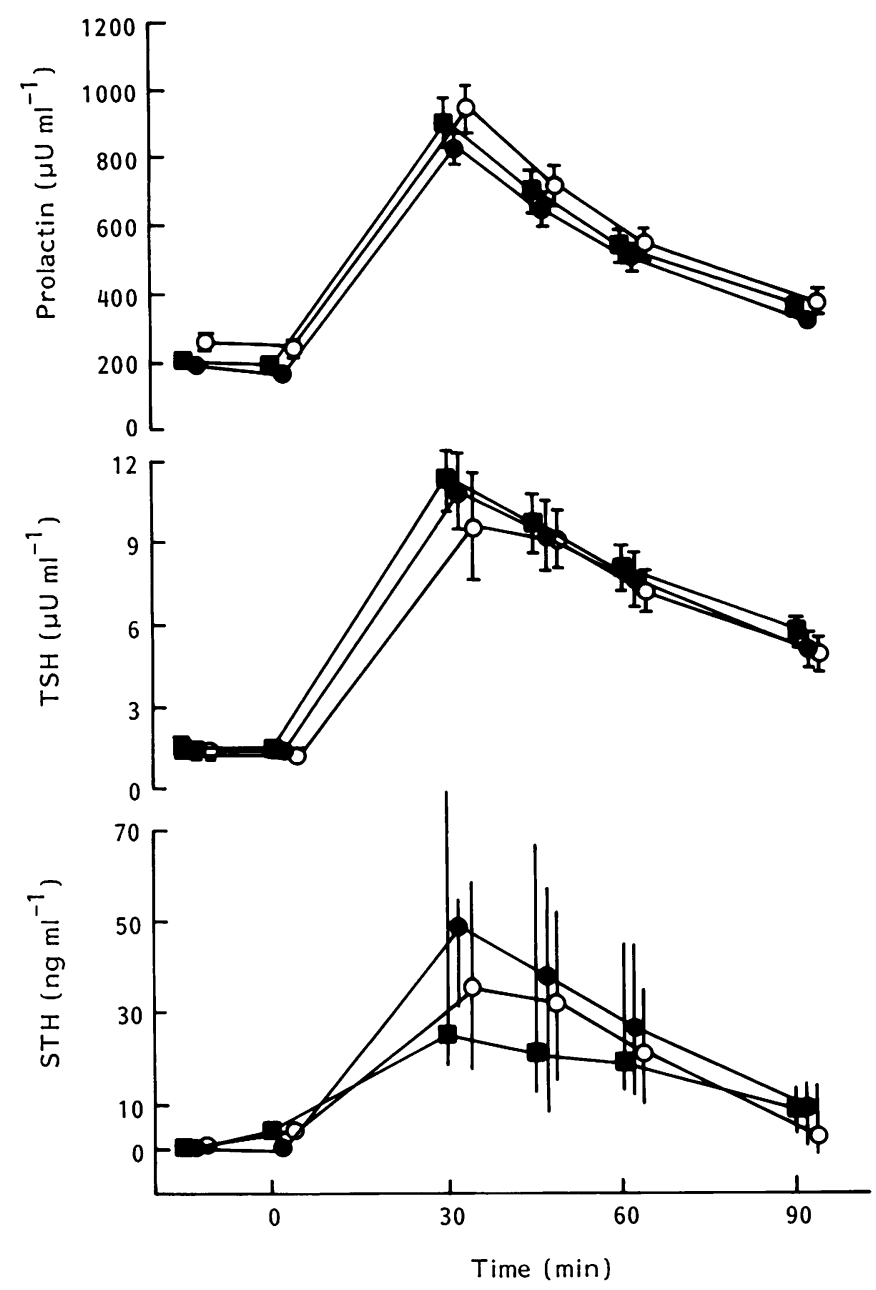

Figure 2. Combined pituitary function test: prolactin, TSH and STH responses to TRH and GHRH did not show any significant changes after 6 weeks of training $(O)$ or after the additional 3 weeks recovery period $(O)$ compared with baseline data ( $\square$ ) (values for PRL and TSH are mean(s.d.); for STH median values and $50 \%$ confidence intervals are given

The training performed did not result in any recognizable change in the hormone levels before (base level) or after maximum exercise (Table 6). A $19-25 \%$ decrease $(P<0.10)$ in free serum testosterone and an approximately $33 \%$ increase in postexercise ACTH concentration, however, cannot be overlooked. The scope of training, and performance level attained, were probably too low to confirm the demonstrable, clear group differences in base hormone levels between high-endurance trained athletes ${ }^{19}$ and the recreational athletes in this study (Table 6) as being primarily training-related (Figures 4 , 5). The base levels of LH, FSH and STH are higher in high-endurance trained individuals - based on this cross-sectional comparison - and base levels of serum prolactin, aldosterone, insulin and free testosterone are lower, than in the recreational athletes examined (Figure 4). The concentrations after maximum exercise showed no significant group differences, or remained constant for the gonadotrophin levels (Figure 5). High or constant gonadotrophin levels, with low free
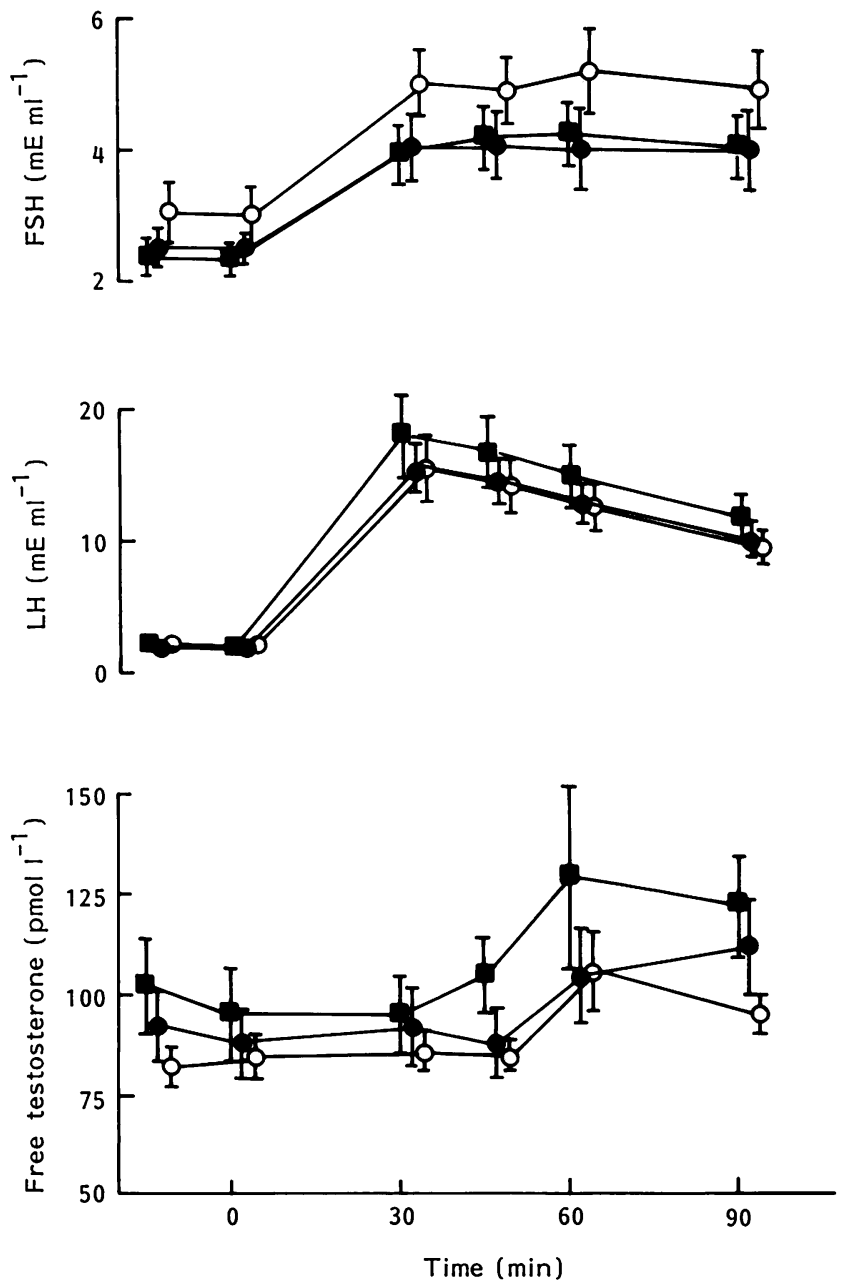

Figure 3. Combined pituitary function test: $\mathrm{FSH}$ and $\mathrm{LH}$ responses to $\mathrm{GnRH}$ and responses of free testosterone to $\mathrm{LH}$. The $\mathrm{FSH}$ response is significantly increased after the recovery period $(O)$, the $\mathrm{LH}$ response significantly decreased after 6 weeks of training $(O)$ and after the additional recovery period $(\mathrm{O})$; the free testosterone responses to $\mathrm{LH}$ show a similar tendency

testosterone concentrations, indicate that the low free testosterone levels are the result of a peripheral mechanism, that is, decreased synthesis or increased metabolic clearance rate.

A training-related alteration in pituitary response can be detected by the pituitary function test (Figures $1-3)$, which is more a test of the maximum pituitary synthesis secretion capacity, as opposed to the observed base or postexercise serum hormone levels (Table 6). The CRH-stimulated pituitary ACTH release is significantly lower after training with reduced ACTH-dependent adrenal cortisol release. It appears hardly plausible to assume that overexertion of the adrenal cortex can be the underlying cause as the subjects had only performed moderate training (in both volume and duration). An increase in cortisol sensitivity of the organism, combined with a reduction in cortisol demand, is more likely. Such an endurance training-related adaptation mechanism has also been discussed for catecholamine ${ }^{20,21}$ and insulin ${ }^{22,23}$. The lower peripheral serum cortisol level 
explains the increase in pituitary ACTH response. TRH-dependent TSH and prolactin release or GHRHdependent STH release do not show any dependence on the training performed (Figure 2).

The elevated GnRH-dependent FSH secretion after training may result from a lower testicular inhibin secretion as a result of altered spermatogenesis ${ }^{24}$, as has been observed in endurance-trained athletes ${ }^{25}$. The trend towards lower testosterone levels may also promote a reduction in spermatogenesis (intratesticular free testosterone) and an increase in pituitary GnRH sensitivity (circulating free testosterone ${ }^{24,26}$ ).
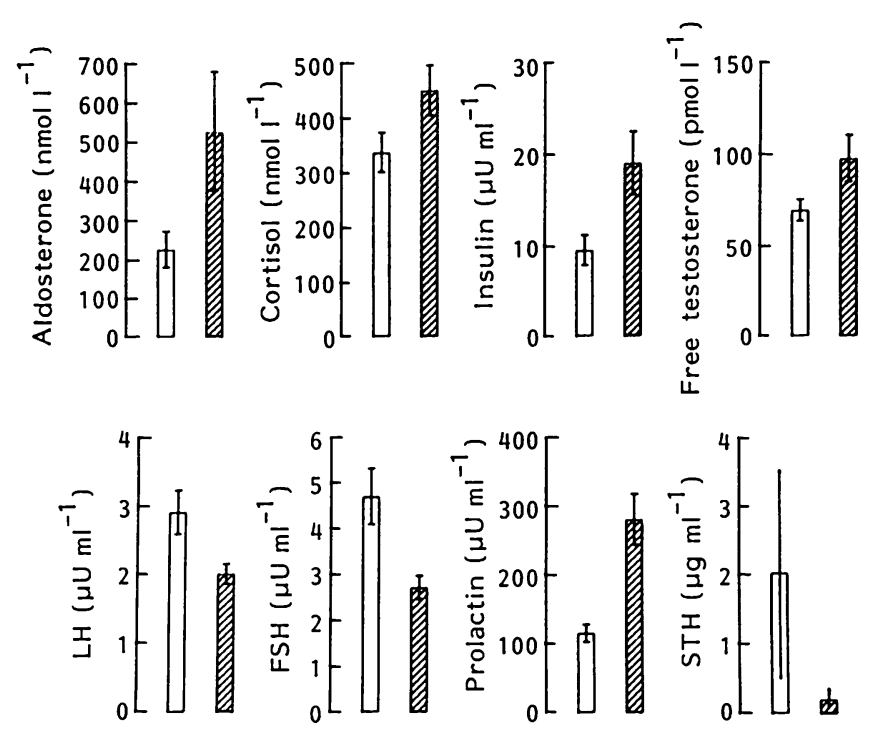

Figure 4. The morning resting hormone concentrations of aldosterone, insulin, fee testosterone, and prolactin are significantly higher in the six recreational athletes (7) compared with highly trained endurance athletes $(\square)^{19}$, cortisol shows a similar tendency. The LH, FSH and STH concentrations are significantly lower in the recreational athletes. Values are mean(s.e.m.)
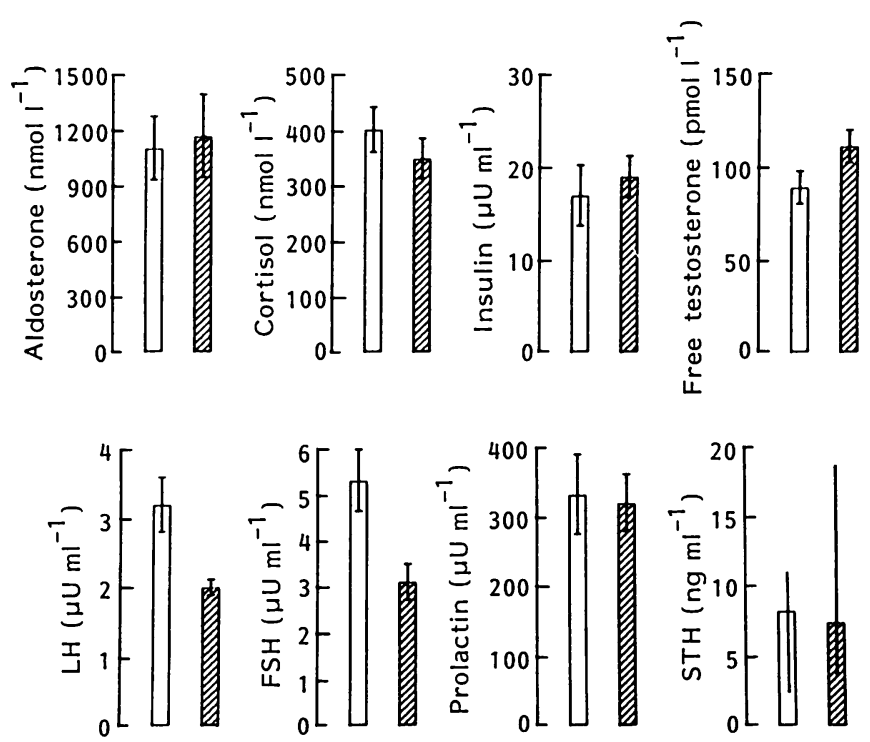

Figure 5. The hormone concentrations after maximum ergometric exercise show no significant differences between the six recreational athletes (a) and highly trained endurance athletes $(\square)^{19}$, except for $\mathrm{LH}$ and FSH concentrations according to Figure 4. Values are mean(s.e.m.)
These observed changes refer only to the range of maximum pituitary FSH response since the serum levels before and after exercise remain unchanged (Table 6). The FSH increased maximum pituitary response may be at the cost of the pituitary LH response and in part explain the reduction of maximum $\mathrm{LH}$ response (Figure 3 ), since FSH and LH are synthesized by the same pituitary cells ${ }^{24,26}$; an inhibition of the LH response by increased $\beta$ endorphin levels ${ }^{24,26}$ - as supposed by analogy to the increased ACTH response - may be of additional significance. A reduction in pituitary LH response was also observed by Hackney et $a l^{5}{ }^{5}$ in a crosssectional examination of trained and untrained individuals. It also applies more to the maximum response - the LH levels before and after exercise remain unaffected ${ }^{5}$ (Table 6).

The temporal course of the observed opposing changes in stimulated FSH and LH response may contradict the above interpretation of the results, since $\mathrm{LH}$ response was already reduced immediately after training and the FSH response was not increased until the next measuring point, that is 3 weeks later (Figure 3). The assumption of an overload-dependent training-related primary reduction in maximum pituitary LH response makes the increase in maximum FSH response appear unlikely, however, because FSH would be expected to decrease and not increase if the gonads are overloaded. A general overloading of the pituitary was not observed by other workers, even in overtraining ${ }^{1}$, nor is it supported by the unchanged pituitary STH, TSH and prolactin responses during our studies (Figure 2). As an explanation of the 'temporal' discrepancy in pituitary FSH and LH responses, it appears more plausible that a change in the secretion of gonadotrophins following the administration of $100 \mu \mathrm{g} \mathrm{GnRH}$ is detected earlier than any change in LH secretion due to the shorter half-life of serum LH, or that there is a lag time in detecting changes in secretion of FSH, due to its considerably longer half-life (approximately $4 \mathrm{~h}$ as compared with $40 \mathrm{~min}$ ) with considerably lower fluctuations in serum levels ${ }^{24,26}$.

In summary, it should be emphasized that the opposing changes in the pituitary gonadotrophin synthesis secretion rate observed during the training study after administration of $100 \mu \mathrm{g} \mathrm{GnRH}$ refer mainly to maximum capacity. The gonadotrophin levels before and after exercise were not affected (Table 6), or even increased in high-endurance trained individuals (Figures 4,5 ). The latter may indicate that the described low testosterone levels in endurancetrained individuals $5,6,19,27$ cannot be attributed to a decrease in gonadotrophins $\mathrm{s}^{27}$. Even in overtrained middle- and long-distance runners, no decrease in FSH and LH levels was observed ${ }^{19}$ as opposed to CRH-related ACTH response or GHRH-dependent STH and TRH-induced prolactin response ${ }^{1}$.

\section{Acknowledgements}

Supported by Bundesinstitut für Sportwissenschaft Köln, Deutsche Forschungsgemeinschaft Bonn (Le 687/1-2) and CIBA Geigy $\mathrm{GmbH}$ Wehr. Many thanks to Ms J. Eysell for translation of our manuscript and to Ms U. Spöri for technical assistance. 


\section{References}

1 Barron JL, Noakes TD, Levy W, Smith C, Millar RP. Hypothalamic dysfunction in overtrained athletes. I Clin Endocrinol Metab 1985; 60: 803-6.

2 Israel S. Zur Problematik des Übertrainings aus internistischer und leistungsphysiologischer Sicht. Med Sport 1976; 16: 1-12.

3 Kuipers H, Keizer HA. Overtraining in elite athletes. Sports Med 1988; 6: 79-92.

4 Keizer HA, Platen $\mathrm{P}$, Koppeschaar $\mathrm{H}$ et al. Blunted $\beta$-endorphin responses to corticotrophin releasing hormone and exercise after exhaustive training. Int J Sports Med 1991; 12: 97.

5 Hackney AC, Sinning WE, Bruor BC. Hypothalamic-pituitary-testicular axis function in endurance-trained males. Int $J$ Sports Med 1990; 11: 298-303.

6 Wheeler GD, Mohan Singh, Pierce WD, Epling WF, Cumming DC. Endurance training decreases serum testosterone levels in men without change in luteinizing hormone pulsatile release. J Clin Endocrinol Metab 1991; 72: 422-5.

7 Bundesgesundheitsamt. Bundeslebensmittelschlüssel II. 1. Berlin, Germany: Bundesgesundheitsamt, 1989.

8 Kluthe B. Prodi III plus. Praxisorientiertes Dialogsystem für Ernährungs- und Diätberatung. Stuttgart, Germany: Wissenschaftliche Verlagsgesellschaft, 1989.

9 Hohorst HJ. L-(+)-Laktat. Bestimmung mit LaktatDehydrogenase und DPN. In: Bergmeyer HU, ed. Methoden der Enzymatischen Analyse. Weinheim, Germany: Chemie, 1962: 266-77.

10 Eddy DO, Sparks KL, Adelizi DA. The effect of continuous and interval training in women and men. Eur J Appl Physiol 1977; 37: 83-92.

11 Gollnick PD, Armstrong RB, Saltin B, Saubert IV CW, Sembrowich WL, Sheperd RE. Effect of training on enzyme activity and fiber composition of human skeletal muscle. $J$ Appl Physiol 1973: 34: 107-11.

12 Henritze J, Weltman A, Schurrer RL, Barlow K. Effects of training at and above the lactate threshold on the lactate threshold and maximal oxygen uptake. Eur J Appl Physiol 1985; 54: 84-8.

13 Hickson RC, Bomze HA, Holloszy JO. Linear increase in aerobic power induced by a strenuous program of endurance exercise. J Appl Physiol 1977; 42: 372-6.

14 Péronnet F, Cléroux J, Perrault H, Cousineau D, Champlain J, Nadeau B. Plasma norepinephrine response to exercise before and after training in humans. J Appl Physiol 1981; 51: 812-5.

15 Winder WW, Hagberg JM, Hickson RC, Ehsani AA, McLane JA. Time course of sympathoadrenal adaptation to endurance exercise training in man. J Appl Physiol 1978: 45; 370-4.
16 Hartmann U, Mader A, Petersmann G, Grabow V, Hollmann W. Verhalten von Herzfrequenz und Laktat während ruderspezifischer Trainingsmethoden. Dtsch Z Sportmed 1989; 40: 200-12.

17 Lehmann M, Dickhuth $\mathrm{HH}$, Gendrich $\mathrm{G}$ et al. Training-overtraining. A prospective, experimental study with experienced middle- and long-distance runners. Int J Sports Med 1991; 12: 444-52.

18 Lehmann M, Baumgartl P, Wiesenack C et al. Training-overtraining: influence of a defined increase in training volume vs. training intensity on performance, catecholamines and some metabolic parameters in experienced middle- and longdistance runners. Eur J Appl Physiol 1992; 64: 169-77.

19 Lehmann M, Petersen KO, Bachl N et al. Training-overtraining: performance and hormones after an inadequate increase in training volume vs. intensity. $\mathrm{Br} J$ Sports Med 1992; 26: 233-42.

20 Bieger WP, Zittel R. Effect of physical activity on $\beta$-receptor activity. In: Knuttgen HG, Vogel JA, Poortmans J, eds. Biochemistry of Exercise. Champaign, Illinois, USA: Human Kinetics, 1982: 715-22.

21 Lehmann M, Dickhuth $\mathrm{HH}$, Schmid P, Porzig H, Keul J. Plasma catecholamines, $\beta$-adrenergic receptors, and isoproterenol sensitivity in endurance and non-endurance trained volunteers. Eur J Appl Physiol 1984; 52: 362-9.

22 Galbo H, Kjaer M, Mikines KJ et al. The influence of physical training on glucose turnover and hormonal responses in insulin-induced hypoglycemia. In: Knuttgen HG, Vogel JA Poortmans J, eds. Biochemistry of Exercise. Champaign, Illinois, USA: Human Kinetics, 1983: 673-7.

23 Galbo $\mathrm{H}$. Endocrinology and metabolism in exercise. Int Sports Med 1981; 2: 203-8.

24 Griffin III JE, Wilson JD. Disorders of the testis. In: Braunwald E, Isselbacher KJ, Petersdorf RG, Wilson JD, Martin JB, Fauci AS, eds. Harrison's Principles of Internal Medicine. New York, USA: McGraw-Hill, 1987: 1807-10.

25 Griffith R, Dressendorfer RH, Wade CE. Testicular function during exhaustive exercise The Physician and Sportsmedicine 1990; 18: 54-64.

26 Daniels GH, Martin JB. Neuroendocrine regulation and disease of the anterior pituitary and hypothalamus. In: Braunwald E, Isselbacher KJ, Petersdorf RG, Wilson JD, Fauci AS, eds. Harrison's Principles of Internal Medicine. New York, USA: McGraw-Hill, 1987: 1694-706.

27 Adlercreutz H, Har̈könen M, Kuoppasalmi K et al. Effect of training on plasma anabolic and catabolic steroid hormones and their response during physical exercise. Int J Sports Med 1986; 7: $27-8$.

\section{BASM - SCOTLAND NEWS}

What's happening in Scotland? We continue to encourage and educate all involved with Sports Medicine as much as possible and to think of new ways of doing this. We watch with great interest further developments both in Scotland, the rest of the UK, and elsewhere. Regular meetings have been established over a number of years both at a local and national level. Most recently we have started a series of small group tutorials held between the West and East which have included anatomy at Glasgow University (a nostalgic sniff of formalin for some!) together with sports science and clinical problems. These are set at a slightly more advanced level and have been much enjoyed. More are planned for the Autumn.

Also we have started to produce a Scottish Sports Medicine newsletter which contains news of developments in Sports Medicine and of as many courses as I can find details of in Sports Medicine and related subjects. With such a large geographical area it provides a useful service for BASM members and other interested groups. It has been particularly encouraging to see an increasing involvement of medical students from Glasgow University who have completed the intercalated Sports Science degree.

Who's doing all this? After our AGM in March the collowing people were elected to the committee:- Dr Evan Lloyd, Chairperson, Dr Brian Walker, Vice-Chairperson and Treasurer, Dr Faith Gardner, Secretary; also Dr Gerry Haggerty, Dr Colin Fettes, Dr Hugh Williamson, Ms Linda Hughes, and Mr Paul Fettes.

For any information contact Faith Gardner at 60 Hunter Road, Crosshouse, Kilmarnock, Ayrshire, KA2 OLD (Tel: 0563 37306) 